\title{
The Role of Congruous Leaders for Behavior Management
}

\section{Rudrarup Gupta*}

Multifarious Projects Group, India and Overseas Reviewer, World Academy of Science and Technology, USA

\section{Short Commentary}

Any organization is the great occupational temple, where dedication is always the prime focus from the perspective of that organizational welfare. So organization needs the concerned people, who must have the perceptual devotion not only to contribute but they must have the utmost zeal to form an alluring cultural synthesis in deed. On the other hand it is going to be really engaging to initiate the amiable metamorphosis of behavior. As per the ultimate custom each employee of an organization does expect the incomparable behavior with a pristine occupational modesty at all. So it shall have the best nicety to create an awesome work environment for ever.

\section{Leader's Concern}

\section{Employee's happiness}

It is altogether very crucial for a leader to concentrate upon this. Because employees are the best asset of an organization, who drag the organization in the highest extent through their mutual understanding and on the other hand remarkable performances, which is generated from behavior only.

\section{Employee's feeling}

Leaders shall have to motivate to all the appointed employees about the prodigious prospect of an organization. That is how a needful feeling shall be automatically grown amongst the employees to contribute a lot for that organization and that shall be counted not only for massive organizational revenue but for the momentous goodwill.

\section{Employee's energy}

Organizational flow largely depends upon the employee. Because their psychological splendor shall be culminated, while they shall have some felicitous opportunities at all to refine their skills and professional dexterity. Leaders do have an indispensible role for initiating their diligent employees [1].

\section{Employee's satisfaction}

It is one of the ravishing considerations from the top level managerial hierarchies. Because this radiant satisfaction can enrich the best organizational magnificence in a befitting manner [2].

\section{Employee's glory}

The requirement of both employees and the organization are having some notable equation here. If they are matched at least from the point of view of recognition, money and acceptance with each and other then employees shall be energized enough to provide the best for the organizational elegance.

In this regard this customized management of behavior shall enrich the organization through an amazing understanding of all the needful departments and their worthy developing paradigm. It is indeed true that leaders do play the compelling role here to reform the organizational behavior and they do truly stimulate their respondents for a beauteous cultural celerity, which is really desirable for an entire organization to be magnificently established for ever.

\section{References}

1. Lavoie A (2015) The 5 Leadership Behaviors You Need to Boost Employee Engagement. Entrepreneur India.

2. Role of a Leader, MSG management study Guide.
*Corresponding author: Gupta R, Academic Researcher, Commercial Manager, Multifarious Projects Group, India and Overseas Editor/Reviewer, American Institute of Science, USA, Tel: +0016179630233; E-mail: rudrarupgupta21@gmail.com

Received January 02, 2017; Accepted February 08, 2017; Published February 16, 2017

Citation: Gupta R (2017) The Role of Congruous Leaders for Behavior Management. Intel Prop Rights. 5: 177. doi: 10.4172/2375-4516.1000177

Copyright: (c) 2017 Gupta R. This is an open-access article distributed under the terms of the Creative Commons Attribution License, which permits unrestricted use, distribution, and reproduction in any medium, provided the original author and source are credited. 